\title{
Review Article \\ Recent Developments for Remediating Acidic Mine Waters Using Sulfidogenic Bacteria
}

\author{
Ivan Nancucheo, ${ }^{1}$ José A. P. Bitencourt, ${ }^{2}$ Prafulla K. Sahoo, ${ }^{2}$ Joner Oliveira Alves, ${ }^{3}$ \\ José O. Siqueira, ${ }^{2}$ and Guilherme Oliveira ${ }^{2}$ \\ ${ }^{1}$ Facultad de Ingeniería y Tecnología, Universidad San Sebastián, Lientur 1457, 4080871 Concepción, Chile \\ ${ }^{2}$ Instituto Tecnológico Vale, Rua Boaventura da Silva 955, 66055-090 Belém, PA, Brazil \\ ${ }^{3}$ SENAI Innovation Institute for Mineral Technologies, Av. Com. Brás de Aguiar 548, 66035-405 Belém, PA, Brazil
}

Correspondence should be addressed to Ivan Nancucheo; inancucheo@gmail.com and Guilherme Oliveira; guilherme.oliveira@itv.org

Received 27 March 2017; Revised 31 July 2017; Accepted 23 August 2017; Published 3 October 2017

Academic Editor: Raluca M. Hlihor

Copyright (c) 2017 Ivan Nancucheo et al. This is an open access article distributed under the Creative Commons Attribution License, which permits unrestricted use, distribution, and reproduction in any medium, provided the original work is properly cited.

Acidic mine drainage (AMD) is regarded as a pollutant and considered as potential source of valuable metals. With diminishing metal resources and ever-increasing demand on industry, recovering AMD metals is a sustainable initiative, despite facing major challenges. AMD refers to effluents draining from abandoned mines and mine wastes usually highly acidic that contain a variety of dissolved metals ( $\mathrm{Fe}, \mathrm{Mn}, \mathrm{Cu}, \mathrm{Ni}$, and $\mathrm{Zn}$ ) in much greater concentration than what is found in natural water bodies. There are numerous remediation treatments including chemical (lime treatment) or biological methods (aerobic wetlands and compost bioreactors) used for metal precipitation and removal from AMD. However, controlled biomineralization and selective recovering of metals using sulfidogenic bacteria are advantageous, reducing costs and environmental risks of sludge disposal. The increased understanding of the microbiology of acid-tolerant sulfidogenic bacteria will lead to the development of novel approaches to AMD treatment. We present and discuss several important recent approaches using low sulfidogenic bioreactors to both remediate and selectively recover metal sulfides from AMD. This work also highlights the efficiency and drawbacks of these types of treatments for metal recovery and points to future research for enhancing the use of novel acidophilic and acid-tolerant sulfidogenic microorganisms in AMD treatment.

\section{Introduction}

Metal mining provides everyday goods and services essential to society. However, this activity has at times caused extensive and sometimes severe pollution of air, vegetation, and water bodies [1]. Streams draining active or abandoned mines and mine spoils are widely considered as hazardous to human health and the environment, but on the other hand, they may also be alternative potential sources of valuable metals $[2,3]$.

Currently, millions of tons of ores are processed every year by the mining industry and are disposed in the form of waste rocks and mine tailings. As higher-grade ores are diminishing, the primary ores that are processed by mining companies are of increasingly lower grade (metal content) and the growing amount of waste material produced by mining operations is consequently significant. The use of lower grade ore was made possible by the development of the flotation technique in the late 19th century, which allowed the separation of metal sulfide minerals from gangue minerals that have no commercial value [4]. As a result of selective flotation, about 95 to $99 \%$ of the ground primary ores end up as fine-grain tailings, in the case of copper ores. The composition of tailings is directly dependent on that of the ore, and therefore they are highly variable, though pyrite $\left(\mathrm{FeS}_{2}\right)$ is frequently the most reactive and dominant sulfide mineral present in tailings wastes [4-6].

Pyritic mine tailings therefore have the potential to become extremely acidic when in contact with surface water. Under oxidizing conditions, pyrite-bearing wastes produce sulfuric acid. The acidic water further dissolves other metals contained in mine waste, resulting in low $\mathrm{pH}$ water enriched with soluble sulfate, $\mathrm{Fe}, \mathrm{Al}$, and other transition metals, known as acid mine drainage (AMD) (Figure 1) [7, 8]. 


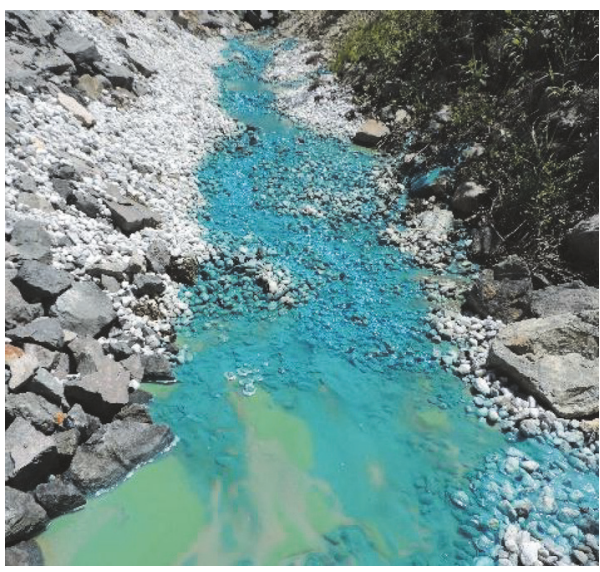

(a)

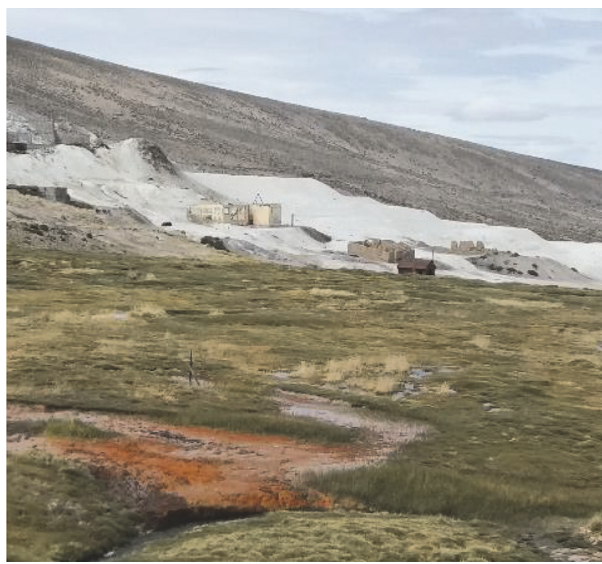

(c)

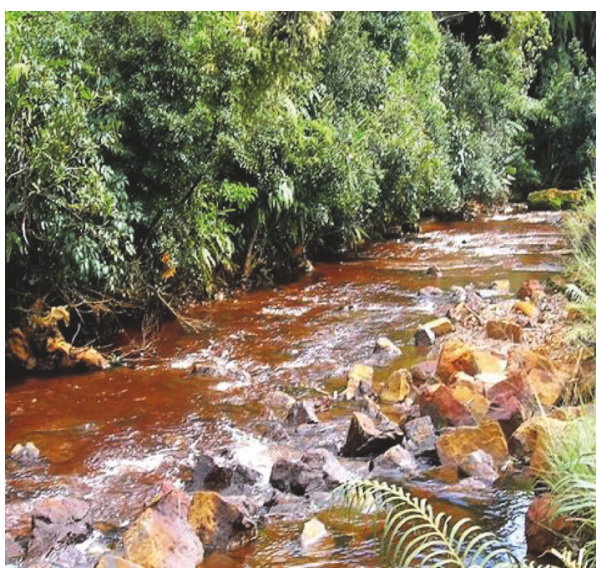

(e)

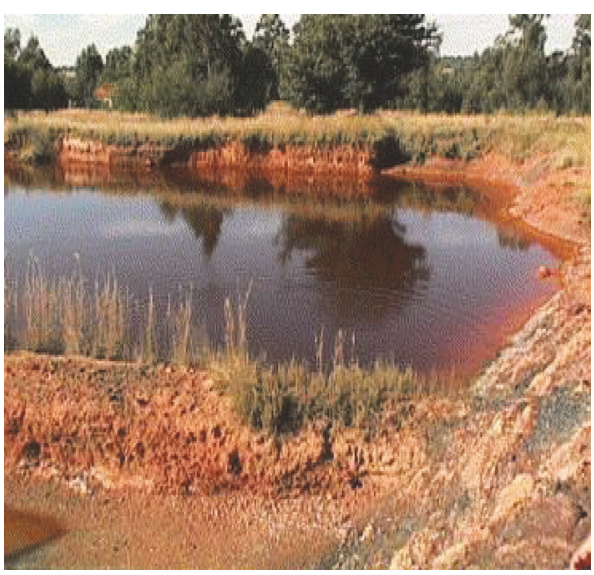

(b)

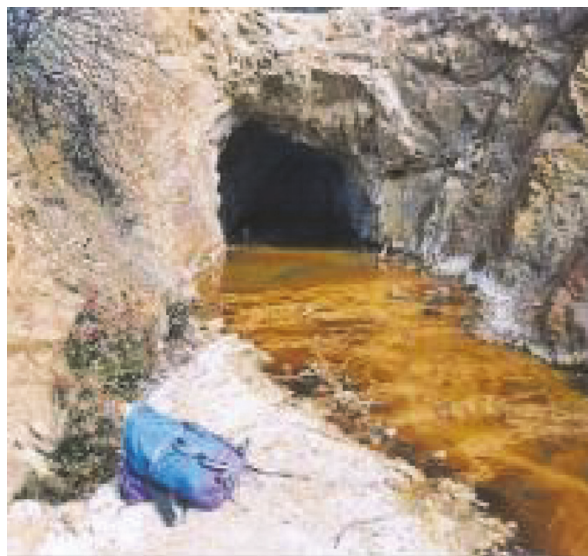

(d)

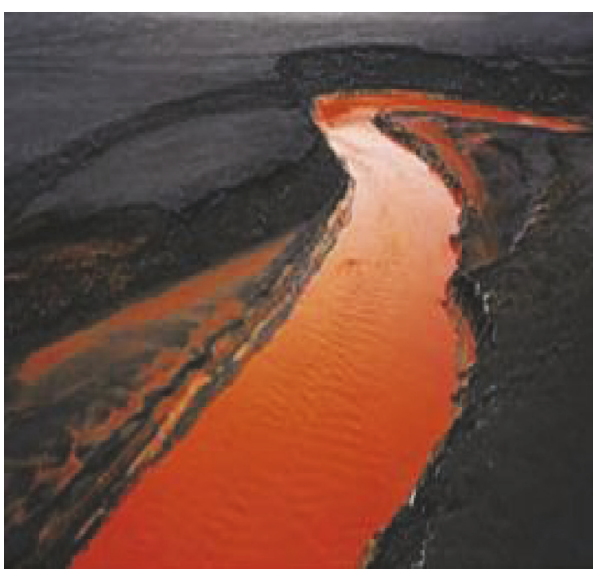

(f)

FIGURE 1: Illustration of streams of acidic waters draining from active or abandoned mines and mine spoils. (a) AMD from a copper mine in the State of Pará, Brazil, that has been remediated with limestone treatment, (b) acidic water released from abandoned underground metalliferous mine in the Republic of South Africa (reproduced from Akcil and Koldas [9]), (c) acidic mine water draining from an abandoned sulfur mine, northern Chile, (d) AMD discharge in the Lomero-Poyatos mine, Spain (reproduced from España et al. [10]), (e) acidic water draining from Coal mines, Jaintia Hills, and (f) AMD originated from mine tailings, Canada, (reproduced from Burtnyski [11]). 


\section{Remediation of Acidic Mine Water}

Waters draining from abandoned metal mines and mine wastes are often acidic $(\mathrm{pH}<4)$ and contain elevated concentrations of dissolved metals and metalloids and high osmotic potential associated with concentration of sulfate salts [14]. In most cases, active chemical treatment and passive biological treatment can provide effective remediation of AMD [15] (details and literature of the advantages and disadvantages of these treatment and others are presented in Table 1). A major drawback to both approaches is that the immobilized metals are contained in "sludge" (chemical treatment) or within spent compost (biological treatment) and need to be disposed in specially designated landfill sites, precluding their recovery and recycling. Changes in redox conditions during storage can lead to remobilization of metals (and metalloids such as arsenic) in both sludge and spent composts. In addition, potentially useful and valuable metal resources are not recovered using conventional approaches for remediating mine waters $[3,16]$.

A radically different approach for remediating AMD which, like compost bioreactors, derives from the abilities of some microorganisms to generate alkalinity and to immobilize metals, is referred to generally as "active biological treatment." Microbiological processes that generate alkalinity are mostly reductive processes and include denitrification, methanogenesis, and dissimilatory reduction of sulfate, ferric iron, and manganese (IV), which tend to be limited in AMD. Considering that AMD usually contains elevated concentrations of both ferric iron and sulfate, the ability of some bacteria to use these compounds as terminal electron acceptors suggests that these reactions can be highly useful for mine water remediation. Acidic environments in which sulfur or sulfide minerals are subjected to biologicallyaccelerated oxidative dissolution characteristically contain large concentrations of soluble sulfate [17]. Therefore, microbial sulfate reduction might be anticipated to occur within anaerobic zones in both acidic and nonacidic environments. Biological sulfidogenesis generates hydrogen sulfide as a result of a reductive metabolic process using sulfate reducing bacteria (SRB). Biological sulfidogenesis has the additional benefits of being a proton-consuming reaction, allowing the increase in $\mathrm{pH}$ of the mine water treated contributing towards mitigation and remediation. The hydrogen sulfide generated can be used in controlled situations to selectively precipitate many potentially toxic metals (such as copper and zinc) often present in AMD at elevated concentrations [3, 18]. Active biological treatment has many advantages over alternative strategies for treating mine waters, one of the most important being its potential for recovering metals that are commonly present in AMD.

There have been few successful applications of SRBmediated active AMD treatment systems, even though this possibility has long been appreciated. One major reason for this is that SRB happens preferentially between $\mathrm{pH} 6$ and 8 [19], whereas AMD generally has a $\mathrm{pH}$ between 2 and 4 and commonly $\mathrm{pH}<3$ [20]. Under these circumstances, a neutralization step is necessary before AMD effluents are subjected to bacterial sulfate reduction or, alternatively, "off-line" systems need to be used. The latter is necessary by the fact that current systems use neutrophilic SRB or sulfur reducing bacteria, and direct exposure to the inflowing acidic solution being treated would be lethal to these microorganisms. Therefore, a separate vessel in which sulfide generated by the bacteria is contacted with the acidic, metal-laden waste water, is required [16, 21]. Examples of this technology are the Biosulfide and Thiopaq processes (Figure 2) operated under the auspices of two biotechnology companies, BioTeq (Canada) and Paques B. V. (The Netherlands), which are currently in operation in various parts of the world.

The Biosulfide process has two stages, one chemical and the other biological. Metals are removed from AMD in the chemical stage by precipitation with biogenic sulfide produced in the biological stage by SRB under anaerobic condition. In this system, hydrogen sulfide is generated by the reduction of elemental sulfur, or other sulfur source, in the presence of an electron donor, such as acetic acid. The gas is passed to an anaerobic agitated contactor in which copper can be precipitated as a sulfide, usually without $\mathrm{pH}$ adjustment and without significant precipitation of other heavy metals present in the water. The end result is a high value copper product, usually containing more than $50 \%$ of the metal. Other metals such as nickel, zinc, and cobalt can also be recovered as separate high-grade sulfide products, although $\mathrm{pH}$ control using an alkali source is usually required to selectively precipitate the metal as a sulfide phase. The high-grade metal sulfide precipitate is then recovered by conventional clarification and filtration to produce a filter cake which can be shipped to a smelter [12].

The Thiopaq process uses another system that involves the use of two biological continuous reactors connected in series (I) to an anaerobic upflow sludge blanket (UASB) reactor for the reduction of oxidized sulfur species. In this reactor, ethanol or hydrogen is utilized by the SRB as electron donor, producing sulfide (mostly $\mathrm{HS}^{-}$) for the precipitation of metal sulfides (which can proceed in the same reactor depending on the toxicity of the wastewater), and (II) an aerobic submerged fixed film (SFF) reactor where the excess sulfide is oxidized to elemental sulfur, using sulfide-oxidizing bacteria. In this process, metals such as $\mathrm{Zn}$ and $\mathrm{Cd}$ can be precipitated down to very low concentrations [22].

The Paques B. V. process has been successfully implemented at an industrial scale at the gold mine Pueblo Viejo, located in the Dominican Republic. A copper recovery plant installed in 2014 based on sulfide precipitation is used to recover the copper liberated from the gold extraction process. The sulfidogenic bioreactor generates $\mathrm{H}_{2} \mathrm{~S}$ to recover up to 12,000 ton of copper per year generating value and reducing the amount of copper sent to the tailing dam [23]. Application of this process has also been demonstrated on a pilot-scale at the Kennecott Bingham Canyon copper mine in Utah, where $>99 \%$ of copper present in a pH 2.6 waste stream was recovered [22, 24, 25].

Sulfate reduction activity has been reported in low $\mathrm{pH}$ ecosystems, for example, in acidic lakes, wetlands, and acid mine drainage $[19,26,27]$. However, few acidophilic/tolerant SRB have been cultured [16, 26, 28-30]. A major potential advantage of using acidophilic sulfidogens would be to allow 


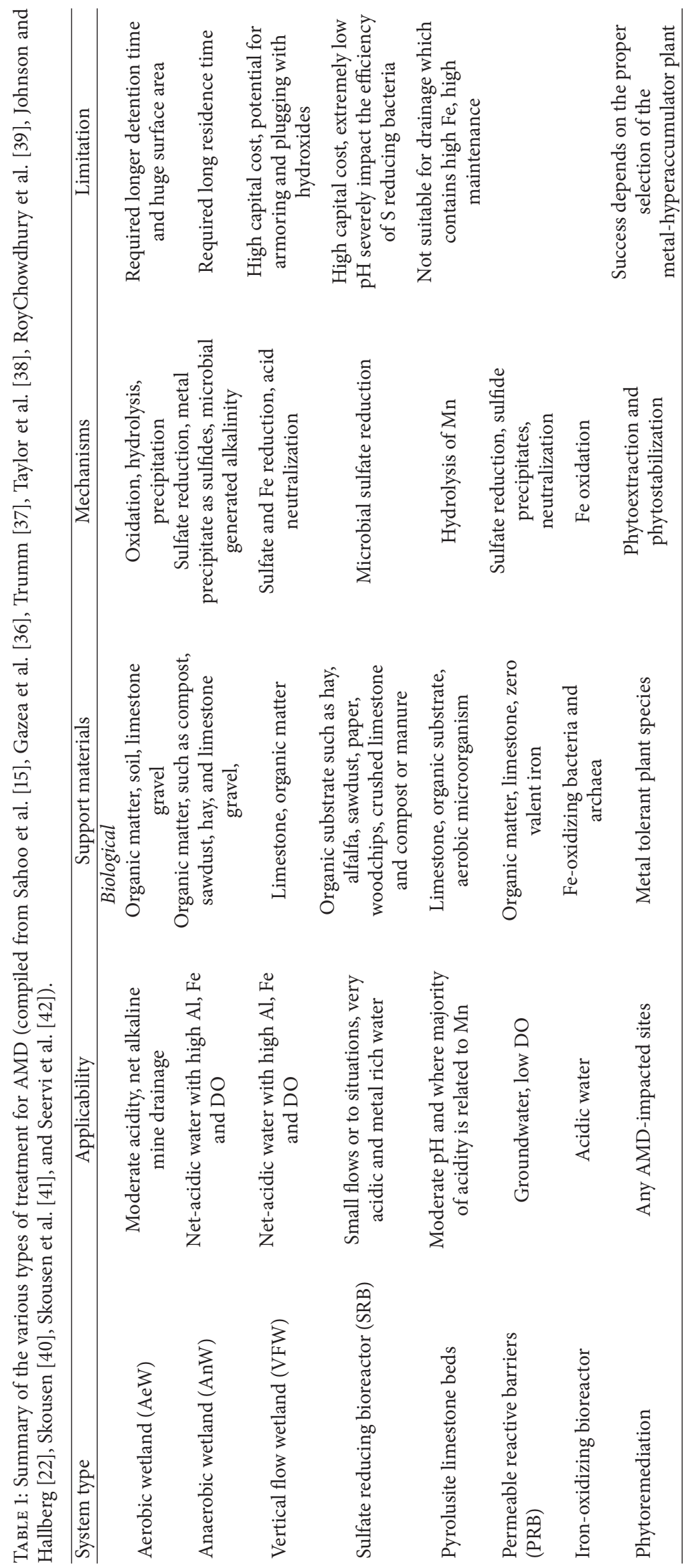




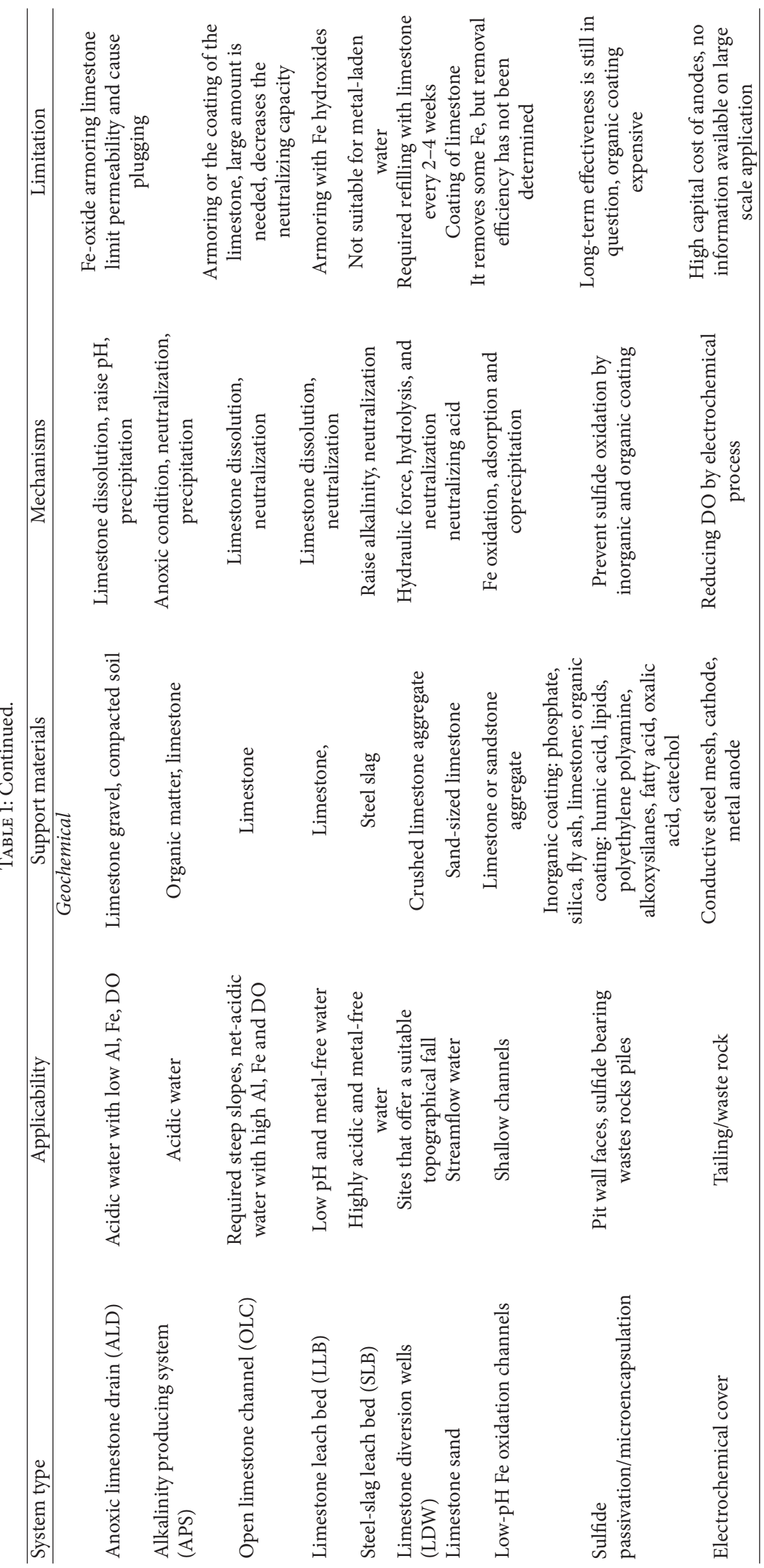




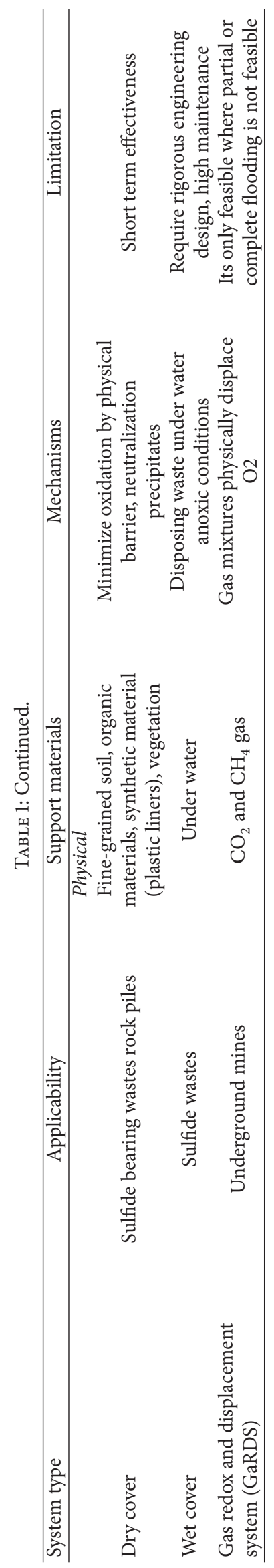




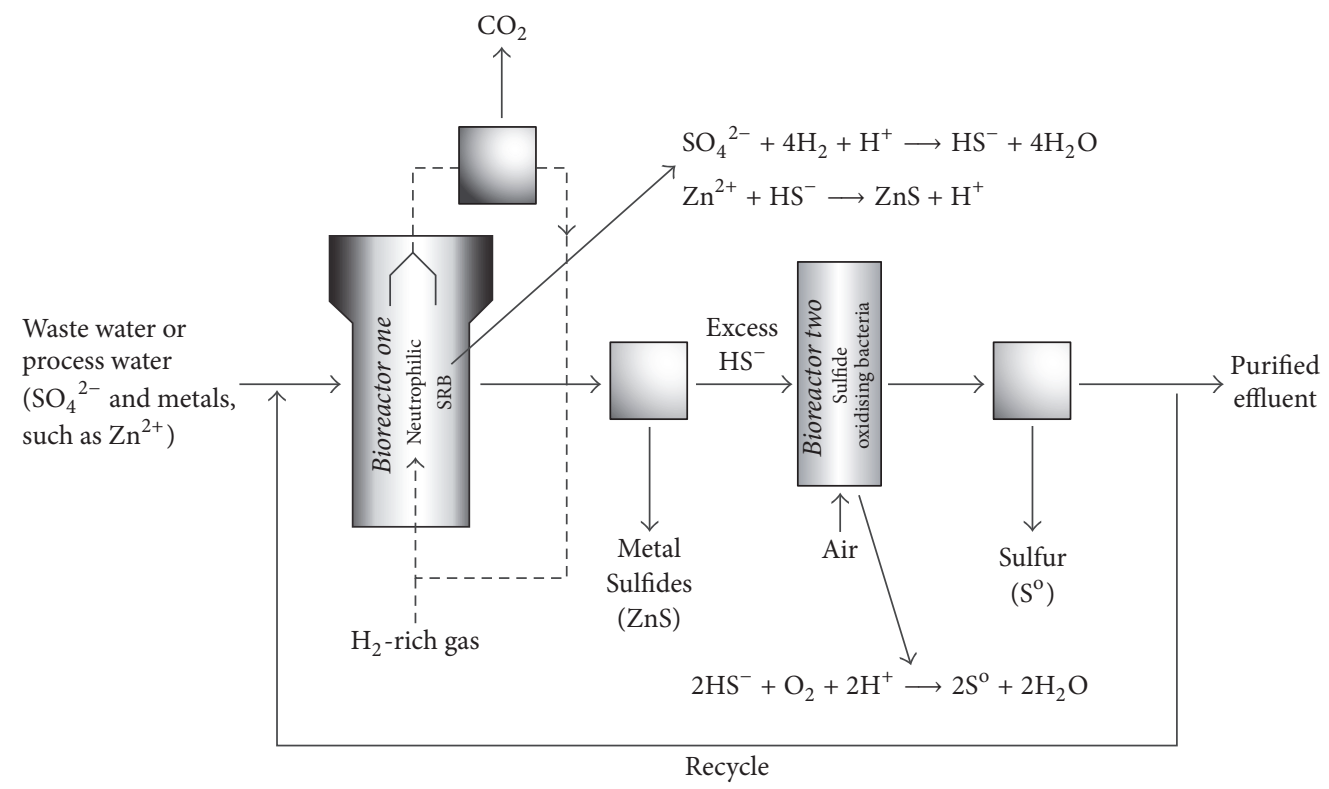

(a)

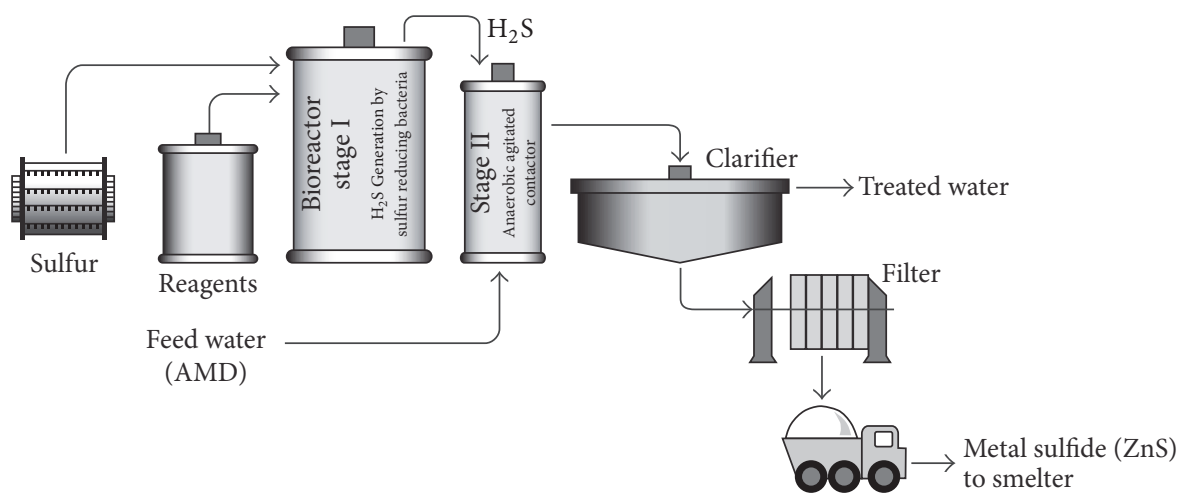

(b)

Figure 2: Schematic overview of the Thiopaq (a) and Biosulfide (b) processes (adapted from Adams et al. [12], Muyzer and Stams [13]).

simpler engineering designs and reduce operational costs by using single on-line reactor vessels that could be used to both generate sulfide and selectively precipitate target metal(s). Precipitation and removal of many soluble transition metals, often present in AMD emanating from metal mines, may be achieved by ready biomineralization as their sulfides. The produced metal sulfides have different solubilities; therefore metals can be precipitated together or selectively by controlling concentrations of the key reactant $\mathrm{S}^{2-}$, which may be achieved by controlling $\mathrm{pH}\left(\mathrm{S}^{2-}+\mathrm{H}^{+} \leftrightarrow \mathrm{HS}^{-}\right)$. Copper sulfide, for example, is far less soluble than ferrous sulfide (respective $\log \mathrm{K}_{\mathrm{sp}}$ values of -35.9 and -18.8) and therefore $\mathrm{CuS}$ precipitates at $\mathrm{pH} 2$, whereas FeS needs much higher $\mathrm{pH}$ to precipitate. Diez-Ercilla et al. [31] have also demonstrated that selective precipitation of metal sulfides occurs naturally in Cueva de la Mora pit lake (SW Spain) and the geochemical calculations match perfectly with the results of chemical and mineralogical composition. Ňancucheo and Johnson [3] showed that it was possible to selectively precipitate stable metal sulfides in inline reactor vessel testing two synthetic AMDs in acidic conditions ( $\mathrm{pH} 2.2-4.8$ ). In the first bioreactor, with a composition of feeding similar to AMD at the abandoned Cwm Rheidol lead-zinc mine in mid-Wales, zinc was efficiently precipitated (>99\%) as sulfide inside the reactor while both aluminum and ferrous iron remain in solution (>99\%) and were washed out of the reactor vessel. The second sulfidogenic bioreactor was challenged with a synthetic AMD based on that from Mynydd Parys, North Wales. Throughout the test period, all the copper present in the feed liquor was precipitated (confirmed as copper sulfide) within the bioreactor, but none of the ferrous iron was present in the solids. Although the initial $\mathrm{pH}$ at which the bioreactor was operated (from $\mathrm{pH} 3.6$ to 2.5) caused some coprecipitation of zinc with the copper, by progressively lowering the bioreactor $\mathrm{pH}$ and the concentration of the electron donor in the influent liquor, it was possible to precipitate $>99 \%$ of the copper within the bioreactor as CuS and to maintain $>99 \%$ of the zinc, iron, and aluminum in 
solution. Glycerol was used as energy and carbon source (electron donor) and the generalized reaction is [1]

$$
\begin{array}{r}
4 \mathrm{C}_{3} \mathrm{H}_{8} \mathrm{O}_{3}+10 \mathrm{H}^{+}+7 \mathrm{SO}_{4}{ }^{2-}+\mathrm{Cu}^{2+}+\mathrm{Zn}^{2+}+\mathrm{Fe}^{2+} \\
\longrightarrow 12 \mathrm{CO}_{2}+5 \mathrm{H}_{2} \mathrm{~S}+\mathrm{CuS}+\mathrm{ZnS}+\mathrm{Fe}^{2+}+16 \mathrm{H}_{2} \mathrm{O}
\end{array}
$$

This low sulfidogenic bioreactor system was also demonstrated to be effective at processing complex acidic water draining from the Mauriden mine in Sweden [18]. Throughout the test period, zinc was removed from the synthetic mine water as $\mathrm{ZnS}$, from which the metal could be recovered, as in the case at the Budel zinc refinery in The Netherlands [24]. Recently, Falagán et al. [32] have operated this sulfidogenic reactor to mediate the precipitation of aluminum in acidic mine waters as hydroxysulfate minerals. Besides, this bioreactor was tested to demonstrate the recovery of over $99 \%$ of the copper present in a synthetic mine water drained from a copper mine in Carajás in the State of Pará, Brazil [33]. The sulfidogenic system was also operated under different temperatures. Although there were large variations in rates of sulfate reduction measured at each temperature, the bioreactor operated effectively over a wide temperature range $\left(30-45^{\circ} \mathrm{C}\right)$ which can have major advantages in some situations where temperatures are relatively high for example in mine sites located in northern Brazil and in other regions where high temperatures are observed. Therefore, there would be no requirements to have temperature control (heating or cooling) to preserve the integrity of the acidophilic SRB reactor [33]. The perceived advantages of this system are that there are simple engineering and relatively low operational cost. The system can be configured to optimize mine water remediation and metal recovery according to the nature of the mine water, which are the constraining factors in using active biological technologies to mitigate AMD.

Metalloids such as arsenic are a common constituent of mine waters. Battaglia-Brunet and colleagues [34] demonstrated that As (III) can be removed by precipitation as a sulfide. The results demonstrated the feasibility of continuous treatment of an acidic solution ( $\mathrm{pH} 2.75-5)$ containing up to $100 \mathrm{mg}$ As (V). Under this approach, As (V) was reduced to As (III) directly or indirectly (via $\mathrm{H}_{2} \mathrm{~S}$ ) by the SRB and orpiment $\left(\mathrm{As}_{2} \mathrm{~S}_{3}\right)$ generated within the bioreactor. In addition, this process was also observed to occur naturally in an acidic pit lake [31].

Recently, Florentino and colleagues [35] studied the microbiological suitability of using acidophilic sulfur reducing bacteria for metal recovery. These authors demonstrated that the Desulfurella strain TR1 was able to perform sulfur reduction to precipitate and recover metals such as copper from acidic waste water and mining water, without the need to neutralize the water before treatment. One drawback on the of use sulfur reducing microorganisms is that a suitable electron donor needs to be added for sulfate reduction. Even though sulfate is present in AMD, the additional cost of electron donors (such as glycerol) for sulfate reduction is higher than the cost of the combined addition of elemental sulfur and electron donors. Subsequently elemental sulfur as an electron acceptor can be more economically attractive for the application of biogenic sulfide technologies. On the other hand, cheaper electron donor such organic waste material may be used but their variable composition makes it less suitable for controlled high rate technologies. Besides, dead algal biomass can release organic products suitable to sustain the growth of SRB. Therefore, Diez-Ercilla et al. [31] have proposed that under controlled eutrophication it could be possible to decrease the metal concentrations in acidic mine pit lakes.

\section{Microbiology in Remediating Acidic Mine Waters}

Based on 16S rRNA sequence analysis, microorganisms that catalyze the dissimilatory reduction of sulfate to sulfide include representatives of five phylogenetic lineages of bacteria (Deltaproteobacteria, Clostridia, Nitrospirae, Thermodesulfobiaceae, and Thermodesulfobacteria) and two major subgroups (Crenarchaeota and Euryarchaeota) of the Archaea domain (Table 2 shows a summary of sulfidogenic microorganisms used for their main characteristics). SRB are highly diverse in terms of the range of organic compounds used as a carbon source and energy, though polymeric organic materials generally are not utilized directly by SRB [13]. In addition, some SRB can grow autotrophically using hydrogen as electron donor and fixing carbon dioxide, though others have requirement for organic carbon such as acetate, when growing on hydrogen. Besides, many SRB can also use electron acceptors other than sulfate for growth, such as sulfur, sulfite, thiosulfate, nitrate, arsenate, iron, or fumarate [78].

Most species of SRB that have been isolated from acidic mine waste such as Desulfosarcina, Desulfococcus, Desulfovibrio, and Desulfomonile are neutrophiles and are active at neutral $\mathrm{pH}[14,25]$. Besides, for a long time the accepted view was that sulfate reducing activity was limited to slightly acidic to near neutral $\mathrm{pH}$ explained by the existence of microniches of elevated $\mathrm{pH}$ around the bacteria [21,31]. Attempts to isolate acidophilic or acid-tolerant strains of SRB (aSRB) have mostly been unsuccessful, until recently [79]. One of the reasons for the failure to isolate aSRB has been the use of organic acids such as lactate (carbon and energy source) which are toxic to many acidophiles. In acidic media, these compounds exist predominantly as nondissociated lipophilic molecules and, as such can transverse bacterial membranes, where they dissociate in the circumneutral internal cell cytoplasm, causing a disequilibrium and the influx of further undissociated acids, and acidification of the cytosol [80]. In contrast, glycerol can be used as carbon and energy source as it is uncharged at low $\mathrm{pH}$. In addition, many SRB are incomplete substrate oxidizers, producing acetic acid as a product, enough to limit the growth of aSRB even at micromolar concentration. To circumvent this problem and for isolating aSRB, overlay plate can be used to remove acetic acid. This technique uses a double layer where the lower layer is inoculated with an active culture of Acidocella (Ac.) aromatica while the upper layer is not. Therefore, the heterotrophic acidophiles metabolize the small molecular weight compounds (such as acetic acid) that derive from acid hydrolysis of commonly used gelling agents 


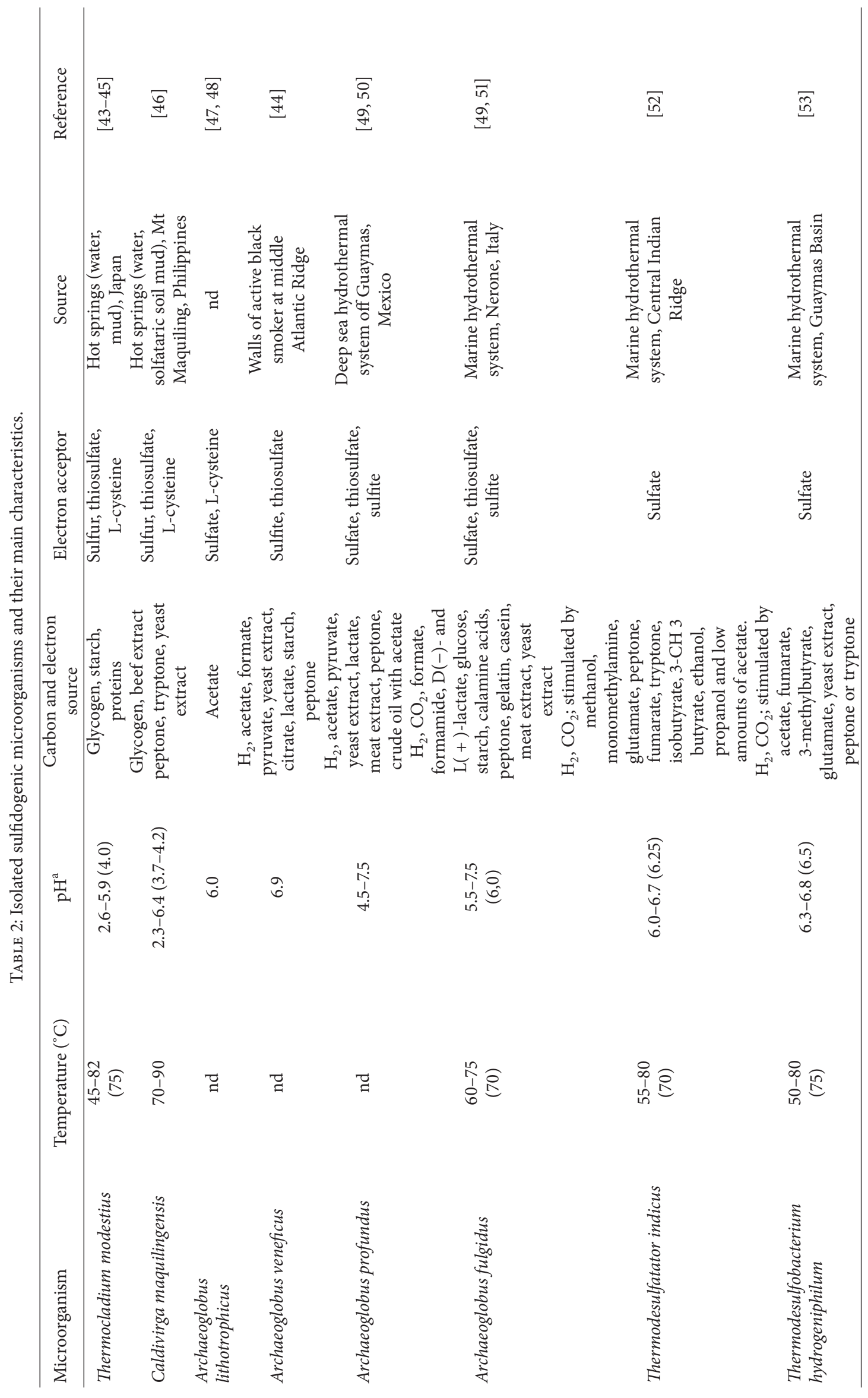




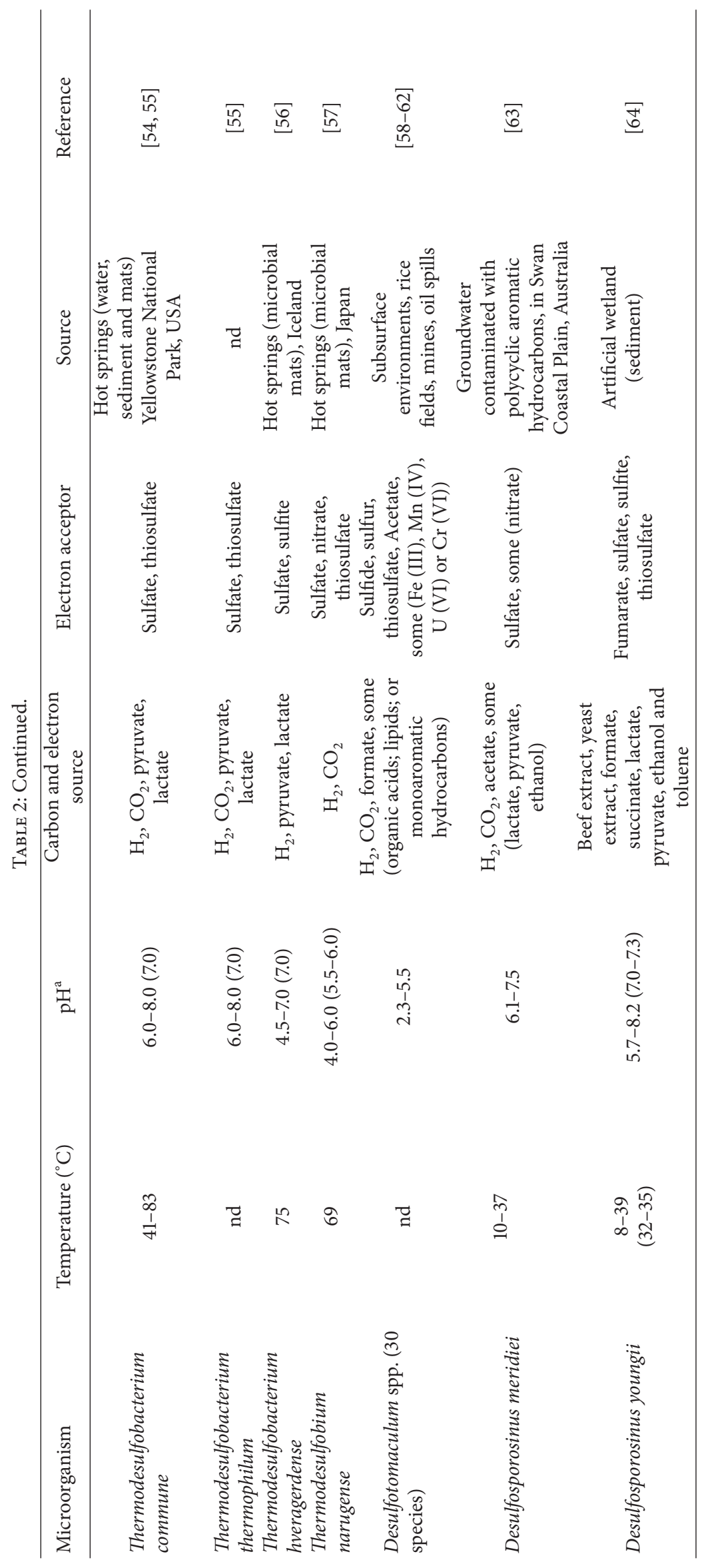




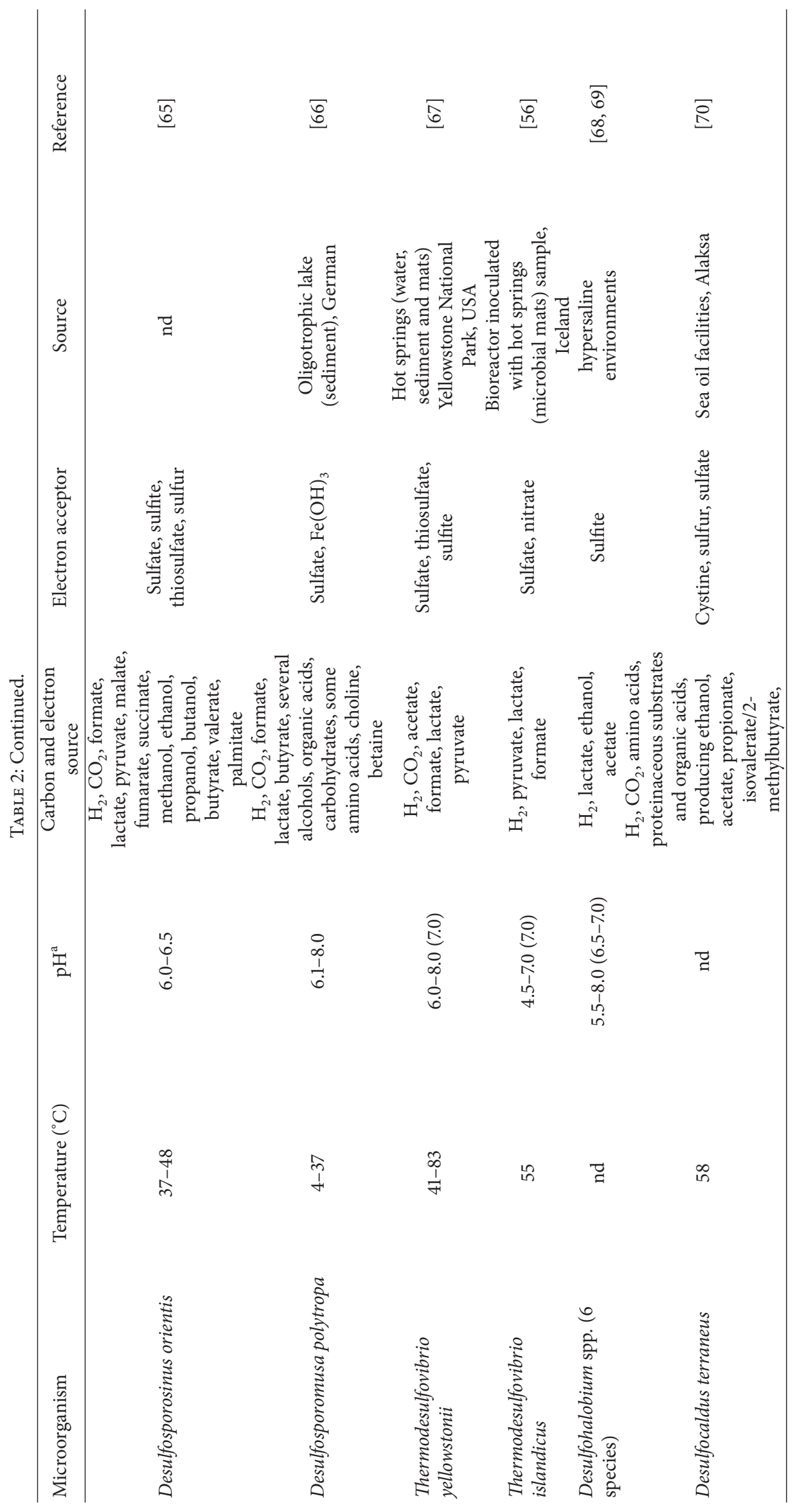




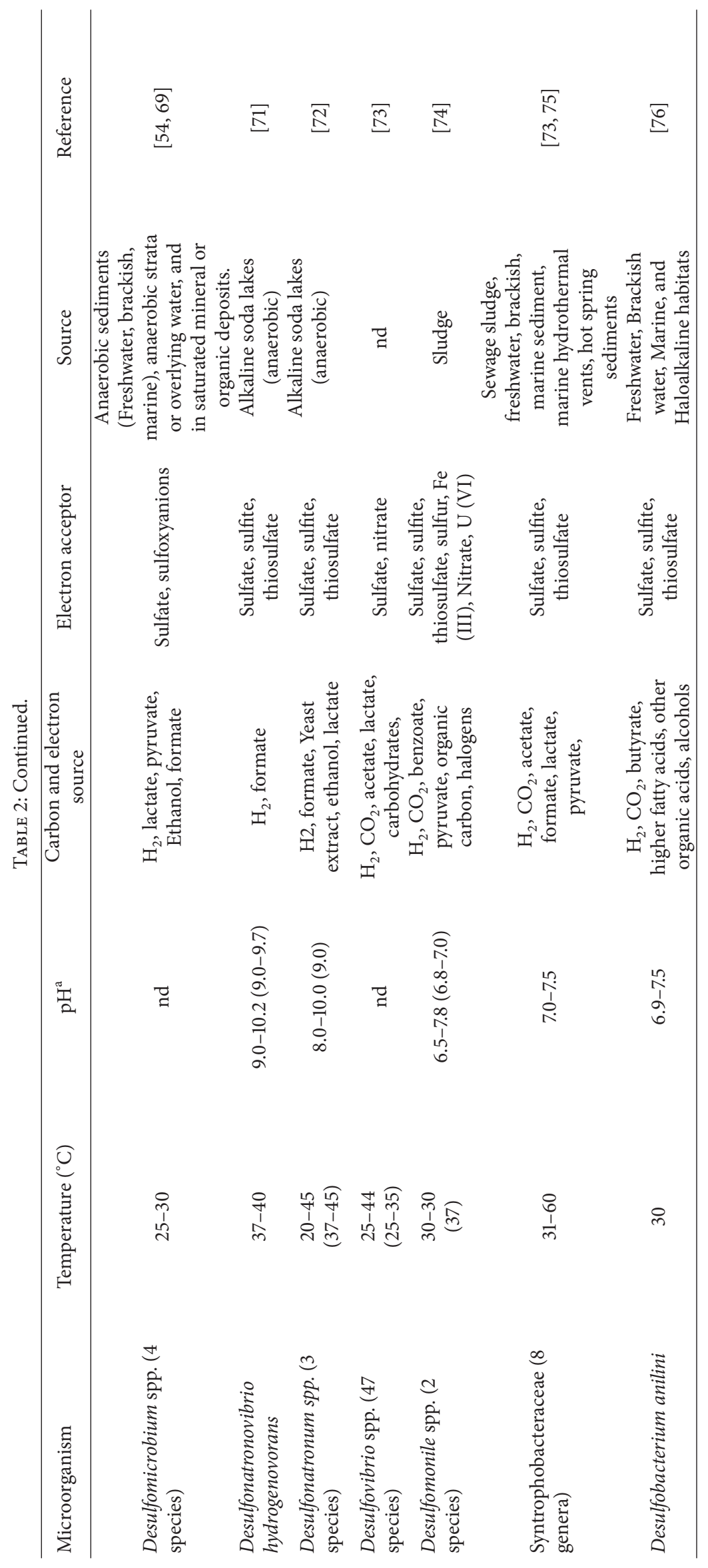




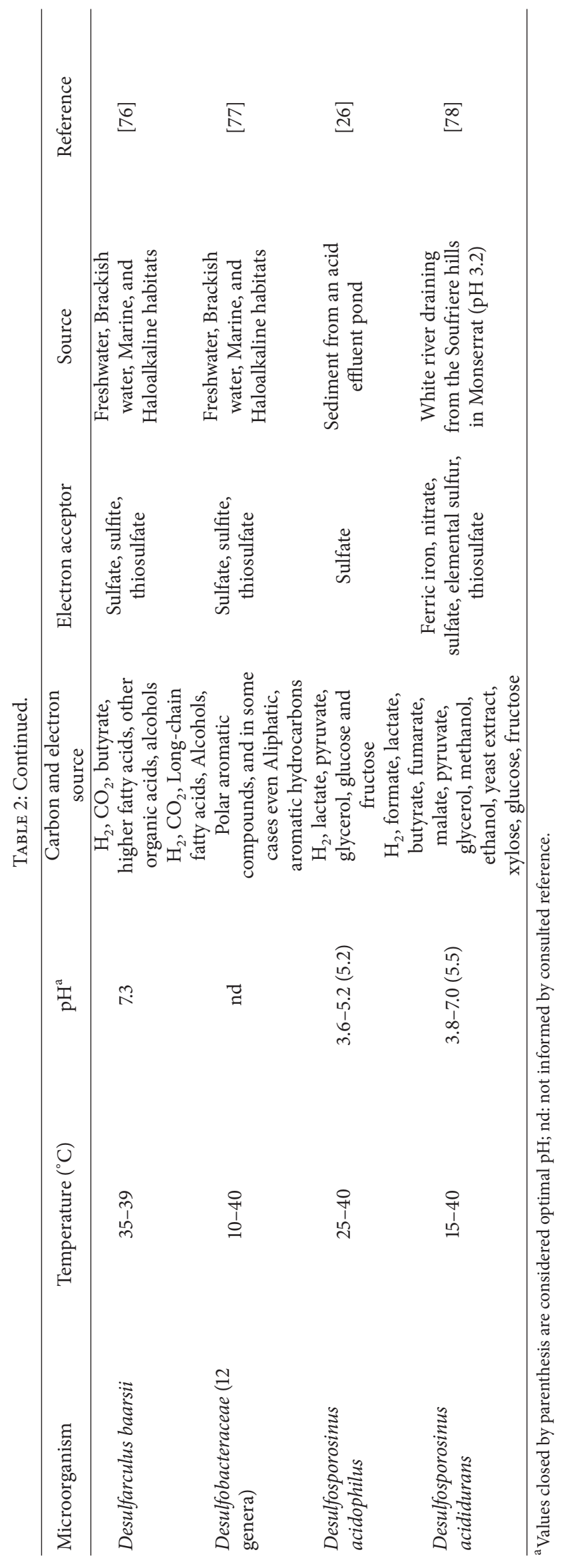


such agar. The advantage of Ac. aromatica is its use of a limited range of organic donors and that it does not grow on yeast extract, glucose, glycerol, or many other small molecular weight organic compounds that are commonly metabolized by acidophilic heterotrophic microorganisms. Overlay plates are considered to be more versatile and efficient, particularly for isolating acidophilic sulfidogens from environmental samples, given that these microorganisms cannot completely metabolize the substrate [20]. Using this technique, aSRB and nonsulfidogens have been isolated from acidic sulfidogenic bioreactors. Two acidophilic sulfidogens (Desulfosporosinus (D.) acididurans and Peptococcaceae strain CEB3) and strain IR2 were all isolated from a low $\mathrm{pH}$ sulfidogenic bioreactor at different stages of operation, previously inoculated with an undefined microbial mat found at abandoned copper mine in Spain [3]. Although not yet fully characterized, Peptococcaceae CEB3 appears to be a more thermotolerant and acidophilic SRB that can oxidize glycerol to $\mathrm{CO}_{2}$ [33].

In addition, $D$. acididurans grew successfully together with Ac. aromatica in a $\mathrm{pH}$ controlled bioreactor, showing an example of microbial syntrophy where this heterotrophic bacterium converted acetic acid into $\mathrm{CO}_{2}$ and $\mathrm{H}_{2}$ [17]. D. acididurans tolerates relatively high concentrations of aluminum and ferrous iron and can grow in a $\mathrm{pH}$ range of $3.8-7$, with and optimum $\mathrm{pH}$ at 5.5. The temperature range for growth was $15-40^{\circ} \mathrm{C}$ with (optimum $\mathrm{pH}$ at $30^{\circ} \mathrm{C}$ ), and it can use ferric iron nitrate, sulfate, elemental sulfur, and thiosulfate as electron acceptors [78]. D. acidophilus, the second acidophilic SRB validly described [26] isolated from a sediment sample collected in a decantation pond receiving acid mine effluent ( $\mathrm{pH} \sim 3.0$ ), showed high tolerance to $\mathrm{NaCl}$. SRB belonging to the genus Desulfosporosinus are known to thrive in low $\mathrm{pH}$ environments together with members of the closely related genus Desulfitobacterium which have also been detected in reactors operating at low $\mathrm{pH}$. Interestingly, Desulfitobacterium is a genus with members that can use sulfite as electron acceptor, but not sulfate. Some bacteria, phylogenetically related to sulfur reducers, have been also detected in AMD bioreactors as well in natural acidic conditions [29].

\section{Natural Attenuation for the Design of AMD Remediation Strategies}

Natural remediation of metal pollutants generally involves the catalytic action of microbial activities that can accelerate the precipitation reaction of soluble toxic compounds resulting in their accumulation in precipitates [81]. Such information from natural systems can be useful for the design of engineered systems. Natural attenuation of transition metals in AMD has been described, for example, at the Carnoulès mine in France [81] and the Iberian Pyrite Belt (IPB) in Spain [10]. Rowe and colleagues [82] described in detail such process at a small site at the abandoned Cantareras copper mine, which is located in the Tharsis, mine district in the IPB. They reported that SRB other than Desulfosporosinus spp. were responsible for precipitating copper (as $\mathrm{CuS}$ ) in a microbial mat found at the bottom layer and dissolved organic carbon (DOC) originated from photosynthetic and chemosynthetic primary producers serving as substrates for the aSRB. The $\mathrm{pH}$ of AMD obtained from this bottom layer was extremely acidic $(\mathrm{pH}<3)$, and the dark grey coloration was due to the accumulation of copper sulfide, presumably as a result of biosulfidogenesis. No iron sulfides (e.g., hydrotroilite; FeS. $n \mathrm{H}_{2} \mathrm{O}$ ) were detected, presumably due to the low $\mathrm{pH}$ of the mine water even at depth. Because the solubility product of $\mathrm{CuS}\left(\log \mathrm{Ksp}\right.$ at $25^{\circ} \mathrm{C}$ is -35.9) is much lower than that of FeS (-18.8), this sulfide mineral precipitates in acidic waters whereas FeS does not.

Furthermore, Sánchez-Andrea and colleagues [83] described in detail the importance of sulfidogenic bacteria of the Tinto River sediments (Spain) and their role in attenuating acid mine drainage as an example of performing natural bioremediation. The results showed that, for attenuation in layers where sulfate reducing genera such as Desulfosporosinus and Desulfurella were abundant, $\mathrm{pH}$ was higher and redox potential and levels of dissolved metals and iron were lower. They suggested that sulfate reducers and the consequent precipitation of metals as sulfides biologically drive the attenuation of acid rock drainage. Lastly, the isolation and further understanding of anaerobic acidophiles in natural environments such as Cantareras and Rio Tinto have led to the proposal of new approaches to selectively precipitate toxic metals from AMD, turning a pollution problem into a potential source of metals $[3,83]$.

\section{Concluding Remarks}

Mining companies are increasing the extraction of mineral resources guided by a higher market demand, and also supported by productivity improvement resultant from advances on prospection and extraction technologies. Increased production consequently results in a higher generation of residues that is a global concern. The mining process has been significantly developed; however, pollution is still one of the main challenges of the mining industry and will require innovative management tools.

Given the fact that protecting aquatic and terrestrial ecosystems from pollutants generated from mine wastes is a major concern, new strategies must be employed such as the application of robust and empirically design bioreactors as part of an integrated system for remediation of acidic mine water and metal recovery. Using novel acidophilic and acid-tolerant sulfidogenic microorganisms that are the key components for bioremediation and knowledge about the microbial interactions that occur in extremely acidic, metalrich environments will help in the development of new methods for bioremediation purposes.

\section{Conflicts of Interest}

The authors declare that there are no conflicts of interest regarding the publication of this paper.

\section{Acknowledgments}

The authors acknowledge the financial support by Conselho Nacional de Desenvolvimento Científico e Tecnológico 
(CNPq) to José O. Siqueira and Guilherme Oliveira and Vale and the sponsorship of SENAI/SESI Innovation Call. Ivan Nancucheo is supported by Fondecyt, Chile (no. 11150170).

\section{References}

[1] D. B. Johnson, "Development and application of biotechnologies in the metal mining industry," Environmental Science and Pollution Research, vol. 20, no. 11, pp. 7768-7776, 2013.

[2] T. Chen, B. Yan, C. Lei, and X. Xiao, "Pollution control and metal resource recovery for acid mine drainage," Hydrometallurgy, vol. 147-148, pp. 112-119, 2014.

[3] I. Ňancucheo and D. B. Johnson, "Selective removal of transition metals from acidic mine waters by novel consortia of acidophilic sulfidogenic bacteria," Microbial Biotechnology, vol. 5, no. 1, pp. 34-44, 2012.

[4] B. Dold, "Sustainability in metal mining: From exploration, over processing to mine waste management," Reviews in Environmental Science and Biotechnology, vol. 7, no. 4, pp. 275-285, 2008.

[5] I. Nancucheo and D. B. Johnson, "Significance of microbial communities and Interactions in Safeguarding reactive mine tailings by ecological engineering," Applied and Environmental Microbiology, vol. 77, no. 23, pp. 8201-8208, 2011.

[6] D. B. Johnson and K. B. Hallberg, "The microbiology of acidic mine waters," Research in Microbiology, vol. 154, no. 7, pp. 466473, 2003.

[7] D. K. Nordstrom, "Advances in the hydrogeochemistry and microbiology of acid mine waters," International Geology Review, vol. 42, no. 6, pp. 499-515, 2000.

[8] P. K. Sahoo, S. Tripathy, M. K. Panigrahi, and S. M. Equeenuddin, "Geochemical characterization of coal and waste rocks from a high sulfur bearing coalfield, India: Implication for acid and metal generation," Journal of Geochemical Exploration, vol. 145, pp. 135-147, 2014.

[9] A. Akcil and S. Koldas, "Acid Mine Drainage (AMD): causes, treatment and case studies," Journal of Cleaner Production, vol. 14, no. 12-13, pp. 1139-1145, 2006.

[10] J. S. España, E. L. Pamo, E. S. Pastor, J. R. Andrés, and J. A. M. Rubí, "The natural attenuation of two acidic effluents in Tharsis and La Zarza-Perrunal mines (Iberian Pyrite Belt, Huelva, Spain)," Environmental Geology, vol. 49, no. 2, pp. 253266, 2005.

[11] E. Burtnyski, Double Threat of Cyanide Leach Mining and Acid Mine Drainage (AMD) Imperils the Futaleufu River ValleyKinross Gold and Geocom Resources Responsible, Mine Tailings, Sudbury Ontario, Canada, 2007.

[12] M. Adams, R. Lawrence, and M. Bratty, "Biogenic sulphide for cyanide recycle and copper recovery in gold-copper ore processing," Minerals Engineering, vol. 21, no. 6, pp. 509-517, 2008.

[13] G. Muyzer and A. J. M. Stams, "The ecology and biotechnology of sulphate-reducing bacteria," Nature Reviews Microbiology, vol. 6, no. 6, pp. 441-454, 2008.

[14] D. K. Nordstrom, D. W. Blowes, and C. J. Ptacek, "Hydrogeochemistry and microbiology of mine drainage: An update," Applied Geochemistry, vol. 57, pp. 3-16, 2015.

[15] P. K. Sahoo, K. Kim, S. M. Equeenuddin, and M. A. Powell, "Current approaches for mitigating acid mine drainage.," Reviews of environmental contamination and toxicology, vol. 226, pp. 1-32, 2013.
[16] D. B. Johnson, A. M. Sen, S. Kimura, O. F. Rowe, and K. B. Hallberg, "Novel biosulfidogenic system for selective recovery of metals from acidic leach liquors and waste streams," Transactions of the Institutions of Mining and Metallurgy, Section C: Mineral Processing and Extractive Metallurgy, vol. 115, no. 1, pp. 19-24, 2006.

[17] S. Kimura, K. B. Hallberg, and D. B. Johnson, "Sulfidogenesis in low $\mathrm{pH}(3.8-4.2)$ media by a mixed population of acidophilic bacteria," Biodegradation, vol. 17, no. 2, pp. 159-167, 2006.

[18] S. Hedrich and D. B. Johnson, "Remediation and selective recovery of metals from acidic mine waters using novel modular bioreactors," Environmental Science and Technology, vol. 48, no. 20, pp. 12206-12212, 2014.

[19] M. Koschorreck, "Microbial sulphate reduction at a low $\mathrm{pH}$," FEMS Microbiology Ecology, vol. 64, no. 3, pp. 329-342, 2008.

[20] T. Jong and D. L. Parry, "Microbial sulfate reduction under sequentially acidic conditions in an upflow anaerobic packed bed bioreactor," Water Research, vol. 40, no. 13, pp. 2561-2571, 2006.

[21] E. Jameson, O. F. Rowe, K. B. Hallberg, and D. B. Johnson, "Sulfidogenesis and selective precipitation of metals at low $\mathrm{pH}$ mediated by Acidithiobacillus spp. and acidophilic sulfatereducing bacteria," Hydrometallurgy, vol. 104, no. 3-4, pp. 488493, 2010.

[22] D. B. Johnson and K. B. Hallberg, "Acid mine drainage remediation options: A review," Science of the Total Environment, vol. 338, no. 1-2, pp. 3-14, 2005.

[23] I. Sánchez-Andrea, A. J. M. Stams, J. Weijma et al., "A case in support of implementing innovative bio-processes in the metal mining industry," FEMS Microbiology Letters, vol. 363, no. 11, pp. $1-4,2016$.

[24] J. Boonstra, R. van Lier, G. Janssen, H. Dijkman, and C. J. N. Buisman, "Biological treatment of acid mine drainage," Process Metallurgy, vol. 9, no. C, pp. 559-567, 1999.

[25] T. Pümpel and K. M. Paknikar, "Bioremediation technologies for metal-containing wastewaters using metabolically active microorganisms," Advances in Applied Microbiology, vol. 48, pp. 135-169, 2001.

[26] D. Alazard, M. Joseph, F. Battaglia-Brunet, J.-L. Cayol, and B. Ollivier, "Desulfosporosinus acidiphilus sp. nov.: A moderately acidophilic sulfate-reducing bacterium isolated from acid mining drainage sediments," Extremophiles, vol. 14, no. 3, pp. 305312,2010

[27] R. A. Gyure, A. Konopka, A. Brooks, and W. Doemel, "Microbial sulfate reduction in acidic ( $\mathrm{pH} 3$ ) strip-mine lakes," FEMS Microbiology Letters, vol. 73, no. 3, pp. 193-201, 1990.

[28] I. Ňancucheo, O. F. Rowe, S. Hedrich, and D. B. Johnson, "Solid and liquid media for isolating and cultivating acidophilic and acid-tolerant sulfate-reducing bacteria," FEMS Microbiology Letters, vol. 363, no. 10, Article ID fnw083, 2016.

[29] I. Sánchez-Andrea, J. L. Sanz, M. F. M. Bijmans, and A. J. M. Stams, "Sulfate reduction at low $\mathrm{pH}$ to remediate acid mine drainage," Journal of Hazardous Materials, vol. 269, pp. 98-109, 2014.

[30] J. M. Senko, G. Zhang, J. T. McDonough, M. A. Bruns, and W. D. Burgos, "Metal reduction at low $\mathrm{pH}$ by a Desulfosporosinusspecies: Implications for the biological treatment of acidic mine drainage," Geomicrobiology Journal, vol. 26, no. 2, pp. 7182, 2009.

[31] M. Diez-Ercilla, J. Sánchez-España, I. Yusta, K. Wendt-Potthoff, and M. Koschorreck, "Formation of biogenic sulphides in the 
water column of an acidic pit lake: biogeochemical controls and effects on trace metal dynamics," Biogeochemistry, vol. 121, no. 3, pp. 519-536, 2014.

[32] C. Falagán, I. Yusta, J. Sánchez-España, and D. B. Johnson, "Biologically-induced precipitation of aluminium in synthetic acid mine water," Minerals Engineering, vol. 106, pp. 79-85, 2017.

[33] A. L. Santos and D. B. Johnson, "The effects of temperature and $\mathrm{pH}$ on the kinetics of an acidophilic sulfidogenic bioreactor and indigenous microbial communities," Hydrometallurgy, vol. 168, pp. 116-120, 2017.

[34] F. Battaglia-Brunet, C. Crouzet, A. Burnol, S. Coulon, D. Morin, and C. Joulian, "Precipitation of arsenic sulphide from acidic water in a fixed-film bioreactor," Water Research, vol. 46, no. 12, pp. 3923-3933, 2012.

[35] A. P. Florentino, J. Weijma, A. J. M. Stams, and I. SánchezAndrea, "Sulfur Reduction in Acid Rock Drainage Environments," Environmental Science and Technology, vol. 49, no. 19, pp. 11746-11755, 2015.

[36] B. Gazea, K. Adam, and A. Kontopoulos, "A review of passive systems for the treatment of acid mine drainage," Minerals Engineering, vol. 9, no. 1, pp. 23-42, 1996.

[37] D. Trumm, "Selection of active and passive treatment systems for AMD - Flow charts for New Zealand conditions," New Zealand Journal of Geology and Geophysics, vol. 53, no. 2-3, pp. 195-210, 2010.

[38] J. Taylor, S. Pape, and N. Murphy, "A summary of passive and active treatment technologies for acid and metalliferous drainage (AMD," in Proceedings of the in Fifth Australian workshop on Acid Mine Drainage, Fremantle, Werstern Australia, 2005.

[39] A. RoyChowdhury, D. Sarkar, and R. Datta, "Remediation of Acid Mine Drainage-Impacted Water," Current Pollution Reports, vol. 1, no. 3, pp. 131-141, 2015.

[40] J. Skousen, "A brief overview of control and treatment technologies for acid mine drainage with special emphasis on passive systems," in Proceedings of the West Virginia Mine Drainage Task Force Symposium, Morgantown, WV, USA, 2016.

[41] J. Skousen, C. E. Zipper, A. Rose et al., "Review of Passive Systems for Acid Mine Drainage Treatment," Mine Water and the Environment, vol. 36, no. 1, pp. 133-153, 2017.

[42] V. Seervi, H. L. Yadav, S. K. Srivastav, and A. Jamal, "Overview of Active and Passive Systems for Treating Acid Mine Drainage," IARJSET, vol. 4, no. 5, pp. 131-137, 2017.

[43] W. Zillig, K. O. Stetter, and W. Schaefer, "Thermoproteales: A novel type of extremely thermoacidophilic anaerobic archaebacteria isolated from Icelandic solfataras," Zentralblatt fur Bakteriologie.Allgemeine Angewandte und Okologische Microbiologie Abt.1 Orig.C Hyg., vol. 2, no. 3, pp. 205-227, 1981.

[44] H. Huber, H. Jannasch, R. Rachel, T. Fuchs, and K. O. Stetter, "Archaeoglobus veneficus sp. nov., a novel facultative chemolithoautotrophic hyperthermophilic sulfite reducer, isolated from abyssal black smokers," Systematic and Applied Microbiology, vol. 20, no. 3, pp. 374-380, 1997.

[45] T. Itoh, K.-I. Suzuki, and T. Nakase, “Thermocladium modestius gen. nov., sp. nov., a new genus of rod-shaped, extremely thermophilic crenarchaeote," International Journal of Systematic Bacteriology, vol. 48, no. 3, pp. 879-887, 1998.

[46] T. Itoh, K.-I. Suzuki, P. C. Sanchez, and T. Nakase, "Caldivirga maquilingensis gen. nov., sp. nov., a new genus of rod- shaped crenarchaeote isolated from a hot spring in the Philippines," International Journal of Systematic Bacteriology, vol. 49, no. 3, pp. 1157-1163, 1999.
[47] J. Vornolt, J. Kunow, K. O. Stetter, and R. K. Thauer, "Enzymes and coenzymes of the carbon monoxide dehydrogenase pathway for autotrophic $\mathrm{CO}_{2}$ fixation in Archaeoglobus lithotrophicus and the lack of carbon monoxide dehydrogenase in the heterotrophic A. profundus," Archives of Microbiology, vol. 163, no. 2, pp. 112-118, 1995.

[48] Y. Boucher, H. Huber, S. L'Haridon, K. O. Stetter, and W. F. Doolittle, "Bacterial origin for the isoprenoid biosynthesis enzyme HMG-CoA reductase of the archaeal orders thermoplasmatales and archaeoglobales," Molecular Biology and Evolution, vol. 18, no. 7, pp. 1378-1388, 2001.

[49] H. Huber, "Hyperthermophilesgeochemical and industrial implications, in Biohydrometallurgical technologies, . Fossil energy, materials, bioremediation, microbial physiology," in Proceedings of an International Biohydrometallurgy Symposium, Torma., M. L. Apel, C. L. Brierley, and A. E. Torma, Eds., pp. 495-505, 1996.

[50] S. Burggraf, H. W. Jannasch, B. Nicolaus, and K. O. Stetter, "Archaeoglobus profundus sp. nov., represents a new species within the sulfate-reducing archaebacteria," Systematic and Applied Microbiology, vol. 13, no. 1, pp. 24-28, 1990.

[51] K. O. Stetter, "Archaeoglobus fulgidus gen. nov., sp. nov.: a new taxon of extremely thermophilic archaebacteria," Systematic and Applied Microbiology, vol. 10, no. 2, pp. 172-173, 1988.

[52] H. Moussard, S. L'Haridon, B. J. Tindall et al., "Thermodesulfatator indicus gen. nov., sp. nov., a novel thermophilic chemolithoautotrophic sulfate-reducing bacterium isolated from the Central Indian Ridge," International Journal of Systematic and Evolutionary Microbiology, vol. 54, no. 1, pp. 227-233, 2004

[53] C. Jeanthon, S. L'Haridon, V. Cueff, A. Banta, A.-L. Reysenbach, and D. Prieur, "Thermodesulfobacterium hydrogeniphilum sp. nov., a thermophilic, chemolithoautotrophic, sulfate-reducing bacterium isolated from a deep-sea hydrothermal vent at Guaymas Basin, and emendation of the genus Thermodesulfobacterium," International Journal of Systematic and Evolutionary Microbiology, vol. 52, no. 3, pp. 765-772, 2002.

[54] E. C. Hatchikian and J. G. Zeikus, "Characterization of a new type of dissimilatory sulfite reductase present in the Thermodesulfobacterium commune," Journal of Bacteriology, vol. 153, no. 3, pp. 1211-1220, 1983.

[55] J. G. Zeikus, M. A. Dawson, and T. E. Thompson, "Microbial ecology of volcanic sulphidogenesis: Isolation and characterization of Thermodesulfobacterium commune gen. nov. and sp. nov., Journal of General Microbiology, vol. 129, no. 4, pp. 11591169, 1983.

[56] J. Sonne-Hansen and B. K. Ahring, "Thermodesulfobacterium hveragerdense sp. nov., and Thermodesulfovibrio islandicus sp. nov., two thermophilic sulfate reducing bacteria isolated from a Icelandic hot spring," Systematic and Applied Microbiology, vol. 22, no. 4, pp. 559-564, 1999.

[57] K. Mori, H. Kim, T. Kakegawa, and S. Hanada, "A novel lineage of sulfate-reducing microorganisms: Thermodesulfobiaceae fam. nov., Thermodesulfobium narugense, gen. nov., sp. nov., a new thermophilic isolate from a hot spring," Extremophiles, vol. 7, no. 4, pp. 283-290, 2003.

[58] T. Aüllo, A. Ranchou-Peyruse, B. Ollivier, and M. Magot, "Desulfotomaculum spp. and related gram-positive sulfatereducing bacteria in deep subsurface environments," Frontiers in Microbiology, vol. 4, article 362, 2013.

[59] A. H. Kaksonen, S. Spring, P. Schumann, R. M. Kroppenstedt, and J. A. Puhakka, "Desulfotomaculum thermosubterraneum 
sp. nov., a thermophilic sulfate-reducer isolated from an underground mine located in a geothermally active area," International Journal of Systematic and Evolutionary Microbiology, vol. 56, no. 11, pp. 2603-2608, 2006.

[60] Y. Liu, T. M. Karnauchow, K. F. Jarrell et al., "Description of two new thermophilic Desulfotomaculum spp., Desulfotomaculum putei sp. nov., from a deep terrestrial subsurface, and Desulfotomaculum luciae sp. nov., from a hot spring," International Journal of Systematic Bacteriology, vol. 47, no. 3, pp. 615-621, 1997.

[61] D. P. Moser, T. M. Gihring, F. J. Brockman et al., "Desulfotomaculum and Methanobacterium spp. dominate a 4- to 5kilometer-deep fault," Applied and Environmental Microbiology, vol. 71, no. 12, pp. 8773-8783, 2005.

[62] C. D. Ogg and B. K. Patel, "Desulfotomaculum varum sp. nov., a moderately thermophilic sulfate-reducing bacterium isolated from a microbial mat colonizing a Great Artesian Basin bore well runoff channel," 3 Biotech, vol. 1, no. 3, pp. 139-149, 2011.

[63] W. J. Robertson, J. P. Bowman, P. D. Franzmann, and B. J. Mee, "Desulfosporosinus meridiei sp. nov., a sporeforming sulfate-reducing bacterium isolated from gasolenecontaminated groundwater," International Journal of Systematic and Evolutionary Microbiology, vol. 51, no. 1, pp. 133-140, 2001.

[64] Y.-J. Lee, C. S. Romanek, and J. Wiegel, "Desulfosporosinus youngiae sp. nov., a sporeforming, sulfate-reducing bacterium isolated from a constructed wetland treating acid mine drainage," International Journal of Systematic and Evolutionary Microbiology, vol. 59, no. 11, pp. 2743-2746, 2009.

[65] R. Bartha, "Sulfate Reducers Revisited The Sulphate-Reducing Bacteria J. R. Postgate," BioScience, vol. 35, no. 5, pp. 319-319, 1985.

[66] H. Sass, J. Overmann, H. Rütters, H.-D. Babenzien, and H. Cypionka, "Desulfosporomusa polytropa gen. nov., sp. nov., a novel sulfate-reducing bacterium from sediments of an oligotrophic lake," Archives of Microbiology, vol. 182, no. 2-3, pp. 204-211, 2004.

[67] E. A. Henry, R. Devereux, J. S. Maki et al., "Characterization of a new thermophilic sulfate-reducing bacterium - Thermodesulfovibrio yellowstonii, gen. nov. and sp. nov.: its phylogenetic relationship to Thermodesulfobacterium commune and their origins deep within the bacterial domain," Archives of Microbiology, vol. 161, no. 1, pp. 62-69, 1994.

[68] B. Ollivier, C. E. Hatchikian, G. Prensier, J. Guezennec, and J.-L. Garcia, "Desulfohalobium retbaense gen. nov., sp. nov., a halophilic sulfate-reducing bacterium from sediments of a hypersaline lake in Senegal," International Journal of Systematic Bacteriology, vol. 41, no. 1, pp. 74-81, 1991.

[69] B. Ollivier, B. K. C. Patel, and J.-L. Garcia, "Desulfohalobium," in Bergey's Manual of Systematics of Archaea and Bacteria, John Wiley \& Sons, Ltd, 2015.

[70] K. E. Duncan, L. M. Gieg, V. A. Parisi et al., "Biocorrosive thermophilic microbial communities in Alaskan North Slope oil facilities," Environmental Science and Technology, vol. 43, no. 20, pp. 7977-7984, 2009.

[71] T. N. Zhilina, G. A. Zavarzin, F. A. Rainey, E. N. Pikuta, G. A. Osipov, and N. A. Kostrikina, "Desulfonatronovibrio hydrogenovorans gen. nov., sp. nov., an alkaliphilic, sulfate-reducing bacterium," International Journal of Systematic Bacteriology, vol. 47, no. 1, pp. 144-149, 1997.

[72] E. V. Pikuta, "Desulfonatronum lacustre gen. nov., sp. nov.: A new alkaliphilic sulfate-reducing bacterium utilizing ethanol," Mikrobiologiya, vol. 67, no. 1, pp. 123-131, 1998.
[73] J. Kuever, F. A. Rainey, and F. Widdel, "Desulfovibrio," in Bergey's Manual of Systematics of Archaea and Bacteria, John Wiley \& Sons, Ltd, 2015.

[74] K. A. DeWeerd, G. Todd Townsend, and J. M. Suflita, "Desulfomonile," in Bergey's Manual of Systematics of Archaea and Bacteria, John Wiley \& Sons, Ltd, 2015.

[75] J. Kuever et al., "The Family Syntrophobacteraceae," in The Prokaryotes: Deltaproteobacteria and Epsilonproteobacteria, E. Rosenberg et al., Ed., pp. 289-299, Springer Berlin Heidelberg, Berlin, Heidelberg, Germany, 2014.

[76] K. Brysch, C. Schneider, G. Fuchs, and F. Widdel, "Lithoautotrophic growth of sulfate-reducing bacteria, and description of Desulfobacterium autotrophicum gen. nov., sp. nov.", Archives of Microbiology, vol. 148, no. 4, pp. 264-274, 1987.

[77] F. Widdel, Anaerober Abbau von Fettsäuren und Benzoesäure durch neu isolierte Arten sulfat-reduzierender Bakterien, GeorgAugust-Universität zu Göttingen, 1980.

[78] I. Sánchez-Andrea, A. J. M. Stams, S. Hedrich, I. Ňancucheo, and D. B. Johnson, "Desulfosporosinus acididurans sp. nov.: an acidophilic sulfate-reducing bacterium isolated from acidic sediments," Extremophiles, vol. 19, no. 1, pp. 39-47, 2015.

[79] M. Dopson and D. B. Johnson, "Biodiversity, metabolism and applications of acidophilic sulfur-metabolizing microorganisms," Environmental Microbiology, vol. 14, no. 10, pp. 26202631, 2012.

[80] P. Norris and W. Ingledew, "Acidophilic bacteria: adaptations and applications," in Molecular biology and biotechnology of extremophiles, R. J. Herbert R.A.a.S., Ed., pp. 115-142, Springer Science+Business media, Glasgow, Scotland, 1992.

[81] O. Bruneel, A. Volant, S. Gallien et al., "Characterization of the Active Bacterial Community Involved in Natural Attenuation Processes in Arsenic-Rich Creek Sediments," Microbial Ecology, vol. 61, no. 4, pp. 793-810, 2011.

[82] O. F. Rowe, J. Sánchez-España, K. B. Hallberg, and D. B. Johnson, "Microbial communities and geochemical dynamics in an extremely acidic, metal-rich stream at an abandoned sulfide mine (Huelva, Spain) underpinned by two functional primary production systems," Environmental Microbiology, vol. 9, no. 7, pp. 1761-1771, 2007.

[83] I. Sánchez-Andrea, K. Knittel, R. Amann, R. Amils, and J. L. Sanz, "Quantification of Tinto river sediment microbial communities: Importance of sulfate-reducing bacteria and their role in attenuating acid mine drainage," Applied and Environmental Microbiology, vol. 78, no. 13, pp. 4638-4645, 2012. 

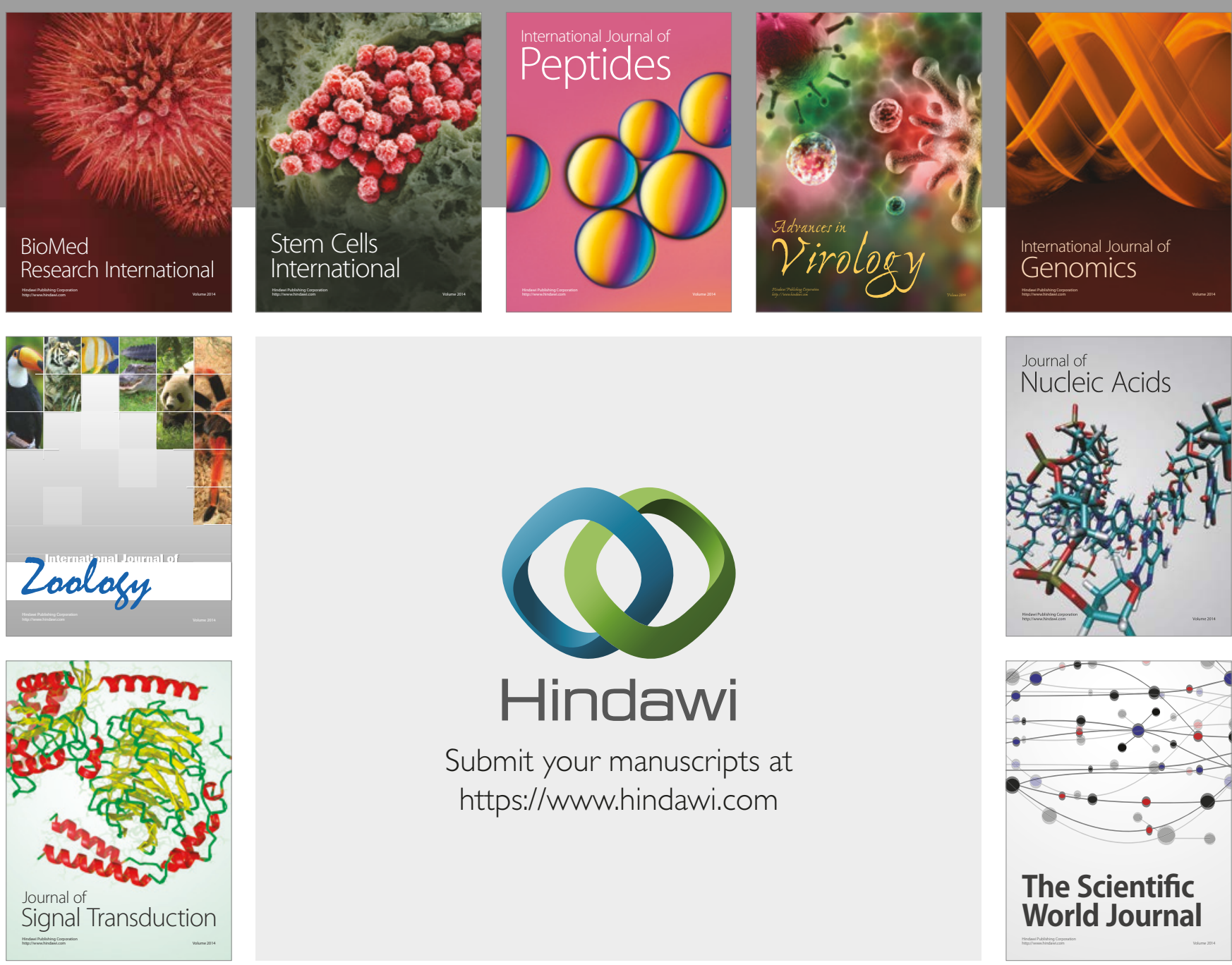

Submit your manuscripts at

https://www.hindawi.com
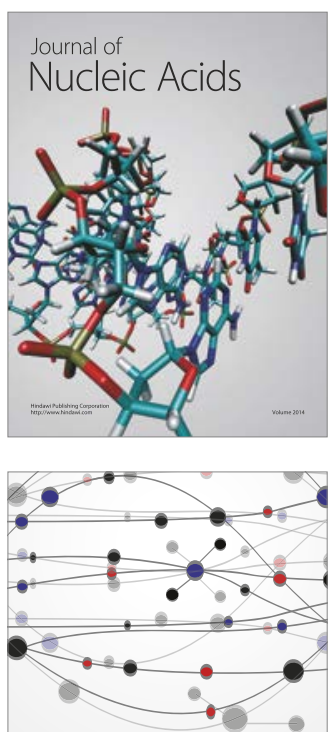

The Scientific World Journal

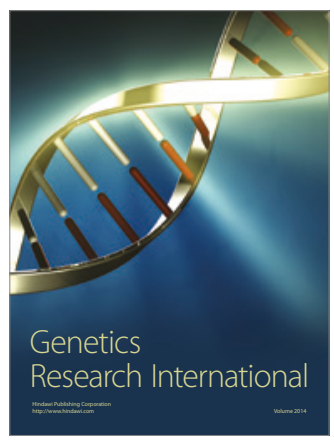

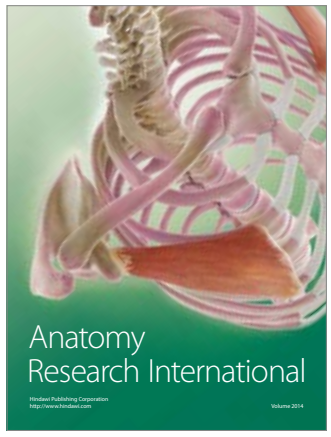

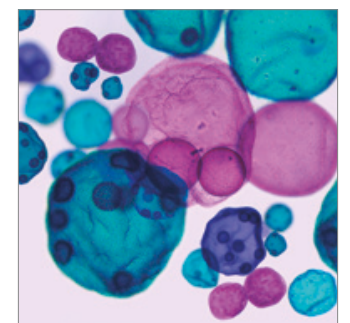

International Journal of Microbiology
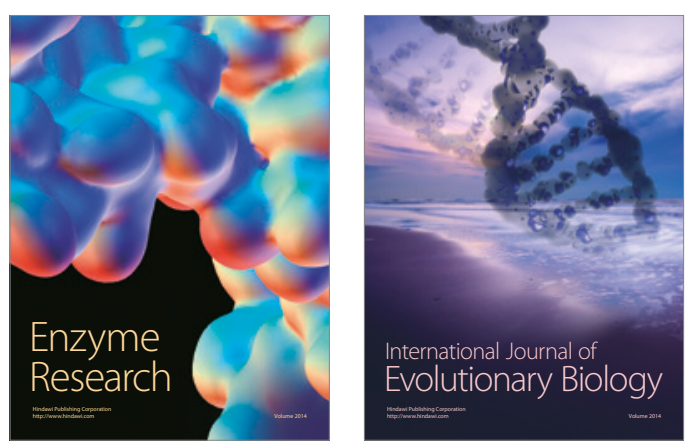
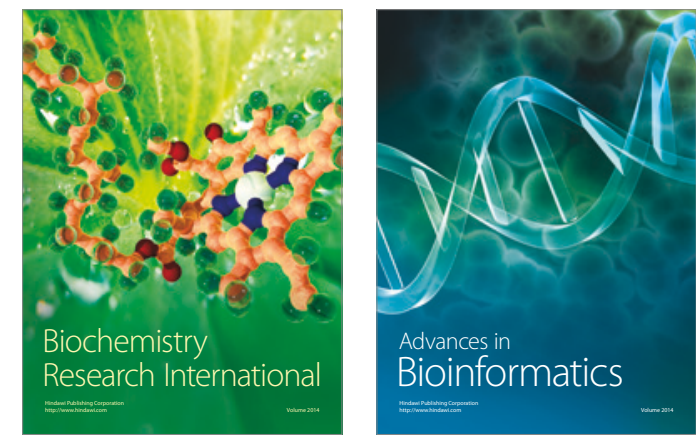

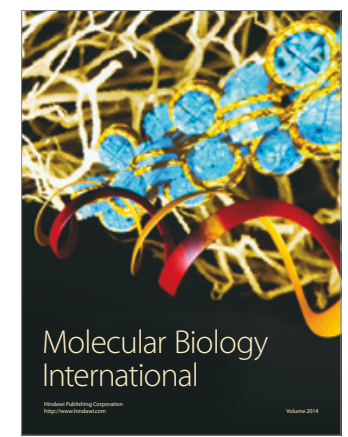

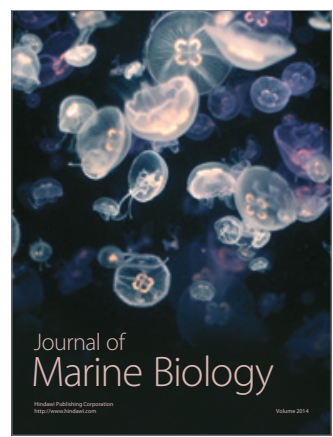

